\title{
Gene-Environment Interaction between $\operatorname{Arg} 72 P r o S N P$ and Selected Environmental Exposures among Brazilian Women Diagnosed with Benign Breast Disease
}

\author{
Rafaela Soares Senra da Costa $^{1}$, Rosalina Jorge Koifman ${ }^{1}$, Viviane Ferreira \\ Esteves $^{2}$, Marla Presa Raulino Schilling ${ }^{1}$, Sergio Koifman ${ }^{1}$, Ilce Ferreira da Silva ${ }^{1 *}$
}

\begin{abstract}
Background: Benign breast disease (BBD) is a factor strongly associated with breast cancer worldwide. Arg $72 P r o$ SNP association with breast cancer is controversial due to the suggestion that environmental factors are required to modulate such risk. There are no studies evaluating these environmental interactions of the aforementioned SNP within BBD. Aim: To determine the frequency of SNP Arg72Pro in a cohort of women diagnosed with BBD; and to investigate gene-environmental interactions with environmental factors. Results: The genotype frequency was $44.6 \%$ for Arg/Pro, 39.3\% for Arg/Arg genotype, and 16.3\% for Pro/Pro homozygote. Gene-environment interaction analysis shows that when Arg/Arg is considered as reference, there is an ORinteraction with Arg/Pro and fabric exposure $(\mathrm{OR}=1.90 ; 95 \% \mathrm{CI}: 1.04,3.48)$, solvents $(\mathrm{OR}=2.21 ; 95 \% \mathrm{CI}: 1.01,4.83)$ and chlorine, bleaches, disinfectants, and liquid wax exposure $(\mathrm{OR}=2.52 ; 95 \% \mathrm{CI}: 1.07,5.91)$. Analysis with Pro/Pro genotype as the reference showed an interaction between alcohol consumption and recessive model $(\mathrm{OR}=1.58 ; 95 \% \mathrm{CI}: 1.00,2.51)$. Gene-environmental interactions were observed too between exposure to hair dyes, straighteners or relaxers and $\mathrm{Arg} / \mathrm{Arg}(\mathrm{OR}=3.26 ; 95 \% \mathrm{CI}: 1.21,8.82)$. Conclusion: The Arg/Pro genotype was the most frequent in the BBD cohort. When compared with the Arg/Arg genotype, the presence of Arg/Pro genotype and solvents, fabric and cleaning products exposure increased the risk of BBD. When compared with Pro/Pro genotype, there were interactions between recessive model with alcohol consumption and exposure to hair products on the risk of BBD.
\end{abstract}

Keywords: Benign breast disease- epidemiology- public health

Asian Pac J Cancer Prev, 21 (12), 3477-3485

\section{Introduction}

Benign breast disease (BBD) is a public health problem, since it constitutes an important breast cancer risk factor, which is the most incident neoplasm among women worldwide (Bray et al., 2018). BBD encompass heterogeneous group of lesions, which are histologically classified according to breast cancer risk (Page and Dupont, 1993). Such classification include non-proliferative lesions, proliferative lesions without atypia, and atypical hyperplasia (College of American Pathologists, 1986), representing a cancer risk varying from 0.8-1.6 among non-proliferative lesions to 2.1-25.2 among atypical hyperplasia (College of American Pathologists, 1986; Dupont and Page 1987; Palli et al., 1991; Bodian et al., 1993; Nomura et al., 1993; Minami et al., 1999; Wrensch et al., 2001). However, biological pathways leading BBD to breast cancer are still unclear.

Evidences suggest BBD occurs when biological mechanisms cannot keep cell integrity greater than $97.5 \%$ and the proliferation process remains constant. Such uncontrolled proliferation activities can originate a potentially pre-cancerous cell, determining BBD histopathological installation, or even breast cancer progression (Chapa et al., 2016). TP53 gene has a genome protective function, through protein repair or induction of apoptosis mechanisms (Donehower et al., 2019). TP53 gene is highly polymorphic, presenting 430 (Bouaoun et al., 2016) so far. There are many studies investigating cancer associations with transversion mutations of guanine (G) to cytosine (C) in exon 4 of codon 72 (rs1042522 SNP), also known as Arg72Pro SNP (Thomas et al., 1999). This SNP encodes two distinct functional alleles, arginine (Arg) and proline (Pro), which results in three distinct genotypes such as the wild genotype Arg/Arg and the mutant genotypes Pro/Pro and Arg/Pro (Thomas et al., 1999). Polymorphic variants transcribe a functionally distinct p53 protein. Evidences suggest that these distinct 
proteins may modulate the risk of cancer development (Dumont et al., 2003; Zhuo et al., 2009).

As far as we know, no study estimated the frequencies of TP53 SNPs in women diagnosed with BBD. However, according to the literature the frequency of TP53 polymorphisms in breast cancer range from $30-50 \%$, with Arg72Pro SNP being the most common in this disease (Done et al., 2001; Tsuda, 2009). Moreover, it has been shown that the allele frequencies of Arg72Pro SNP vary among healthy and sick women, depending on the country and continent. Differences can be explained by the fact that these studies were developed among different ethnic populations, which may affect allele frequencies and environmental exposures (Själander et al., 1996). Authors of case-control studies developed on ethnic mixture populations, such as Brazil, observed that, when compared with women with $\mathrm{Arg} / \mathrm{Arg}$ genotype, those with at least one Pro allele presented higher risk of breast cancer, ranging from 0.99 (95\% CI; 0.59-1.65) in the Southeast region,(Mayorano, 2008) to $2.90(95 \% \mathrm{CI}, 1.43-3.60)$ in the Southern region (Damin et al., 2006). Besides the considerable ethnic variation in Brazil, environmental factors also vary throughout the country, reflecting cultural differences among Brazilian regions that influence in diet, smoking and alcohol habits, lifestyle, and environmental exposures such as those to benzene, heavy metal etc (Ellingjord-Dale et al., 2017; Kresovich et al., 2019; Ma et al., 2019). Furthermore, biological mechanisms by which this gene-environment relationship modulates the risk of breast cancer are still a target of investigation.

Despite that, no study so far evaluated the frequency of the Arg72Pro SNP in women with BBD as well as gene-environmental interactions between Arg72Pro SNP and environmental exposures among these women.Thus, the aim of our study is to determine the frequency of Arg72Pro SNP in a cohort of Brazilian women diagnosed with $\mathrm{BBD}$; and to investigate gene-environmental interactions with selected environmental factors regarding the risk of benign breast disease.

\section{Materials and Methods}

A cross-sectional study was carried out in cohorts of women diagnosed with BBD referred to the outpatient clinics of Fernandes Figueira National Institute (FFI/Fiocruz) and the Federal Hospital of Lagoa (FHL), which are BBD reference units in the city of Rio de Janeiro, Brazil. Baseline cohorts comprises women with altered breast tests (mammography, ultrasonography, and Fine Needle Aspiration - FNA) referred to FFI and FHL from July 2013 to July 2018. Histopathological confirmations were proceeded by core-biopsy, excisional biopsy, and/or surgery. The Ethics Committee Board of both FFI/Fiocruz and the National School of Public Health Sérgio Arouca/FIOCRUZ approved the protocol of this study. All included women formally agreed to participate by signing the informed consent form.

Eligibility criteria included women aged over 17 years at interview, with confirmed histopathological results of BBD. Women with history of breast cancer and/or previous $\mathrm{BBD}$, and those diagnosed with cognitive conditions limiting the understanding of the informed consent form, were excluded. From 373 women included, 14 (3.7\%) refused to participate in the study, whereas 359 women (96.2\%) signed the informed consent form. Among the included women, 327 (91.1\%) had complete questionnaire and blood sample available; however, $2(8.9 \%)$ of them showed nonspecific bands in the amplification step and were not included in the analysis. Thus, analyses included 325 women (90.5\%) who presented a complete questionnaire and DNA genotyping (Figure 1).

An interview-based questionnaire was proceeded to collect data concerning sociodemographic characteristics, clinical aspects, and selected environmental exposures (smoking habit, alcohol consumption, and domestic and occupational chemical exposures). Such instrument was adapted from validated scales (IARC Working Group on the Evaluation of Carcinogenic Risks to Humans 2004, 2010), and it was applied by three trained nurses. Clinical evaluation included weight and height measurements, using a Filizola ergometer scale, regularly calibrated according to Inmetro (1994) criteria. An inelastic tape measure assessed waist and hip measurements. Information on clinical conditions and histopathological outcomes were obtained from physical and electronic medical reports. Two 4-mL tubes of peripheral blood samples were collected, stored at $4^{\circ} \mathrm{C}$, and processed at the Laboratory of Molecular Epidemiology of Cancer (ENSP/FIOCRUZ).

Genomic DNA was extracted from leukocytes using the salting out technique, and then diluted in deionized water (Miller et al., 1988). DNA quality was evaluated by spectrophotometric technique (Nanodrop ${ }^{\circledR}$ ), and $0.1-10$ $\mu \mathrm{l}$ of DNA was subsequently used for TP53 amplification through polymerase chain reaction (PCR) analysis. Forward and reverse primers used for amplification of the $296 \mathrm{bp}$ fragment of polymorphic region were, respectively, 5'-ATCTACAGTCCCCCTTGCCG -3' and 5'-GCAACT GACCGTGCAAGTCA-3'. Arg72Pro SNP genotyping was performed by the PCR-RFLP method (Kumar and Dunn, 1989).

PCR was performed using approximately $1.0-4.0 \mu \mathrm{l}$ of genomic DNA, 0.15 U of Taq-DNA Polymerase Platinum enzyme (Invitrogen, São Paulo, Brazil), 10 pmol of each primer pair, and $5 \mathrm{mM}$ dNTPs in $25 \mu \mathrm{l}$ final volume. PCR conditions were $94^{\circ} \mathrm{C}$ for 5 minutes for initial denaturation, followed by 35 cycles of denaturation at $94^{\circ} \mathrm{C}$ for 30 seconds, annealing at $68^{\circ} \mathrm{C}$ for 30 seconds, and extension at $72^{\circ} \mathrm{C}$ for 40 seconds. The final elongation step was performed at $72^{\circ} \mathrm{C}$ for 7 minutes. After PCR, a $4-\mu 1$ aliquot was removed and digested with the BstU1 restriction enzyme (New England Biolabs, Beverly, MA) at $60^{\circ} \mathrm{C}$ for at least 6 hours. Digested DNA was subjected to a 3\% agarose gel electrophoresis. Gels were photographed in a translucent UV light. The presence of wild Arg allele was indicated by two bands of $169 \mathrm{bp}$ and $127 \mathrm{bp}$, whereas absence of digestion of mutant Pro allele was observed by a single band of $296 \mathrm{bp}$.

Sociodemographic characteristics were compared between the cohorts of women treated in IFF/Fiocruz and HFL, using the Pearson Chi-square test, and no statistically significant differences were observed. Among women 
included in the study, distributions of age, skin color, and BBD were compared between those whose blood samples were lost $(\mathrm{N}=34)$, and those who were included in the analysis $(\mathrm{N}=338)$, using the chi-square and Fisher's tests; moreover, no statistically significant differences were observed.

Hardy-Weinberg Equilibrium (HWE) was estimated for Arg72Pro SNP (rs1042522), according to the reference unit, using Chi-square test (5\% significance level). Statistical program R, version 3.4.3, was used in this analysis. Distributions of genotypes of the Arg72Pro SNP were at HWE in both units (Table-1). Distributions of Arg72Pro SNP genotypes were evaluated according to BBD histological type. Differences between frequencies were verified using the Chi-square test, with 5\% significance level.

Interaction odds ratios, and respective 95\% confidence intervals, between Arg72Pro SNP and selected environmental factors were evaluated considering both Arg/Arg genotype and Pro/Pro genotype as reference, using case-only approach (Piegorsch et al., 1994; Yang and Khoury, 1997). Case-only design has been promoted as an efficient and valid approach to gene-environment interaction screening under the assumption of independence between exposure and genotype in the population (Piegorsch et al., 1994). If one's primary interest is assessing possible interaction between genetic and environmental factors in the etiology of a disease, one may do so without employing control subjects (Yang and Khoury, 1997). According to Yang and Khoury (1997) the odds ratio calculated from a case-only design is related to the odds ratios for exposure alone, for genotype alone, and for their joint effects in the case-control design by the following formula:

$$
\mathrm{OR}_{\mathrm{ca}}=\mathrm{R}_{\mathrm{ge}} /\left(\mathrm{R}_{\mathrm{e}} * \mathrm{R}_{\mathrm{g}}\right) * \mathrm{OR}_{\mathrm{co}},
$$

where $\mathrm{OR}_{\mathrm{ca}}$ is the case-only odds ratio, and $\mathrm{OR}_{\mathrm{CO}}$ is the odds ratio among control subjects relating exposure

Table 1. Arg72Pro SNP Genotype Distribution, According to Reference Units

\begin{tabular}{cccc}
\hline & $\begin{array}{c}\text { Observed } \\
\mathrm{N}(\%)\end{array}$ & $\begin{array}{c}\text { Expected } \\
\mathrm{N}(\%)\end{array}$ & $\mathrm{p}$-value \\
\hline Overall $^{\mathrm{a}}$ & & & \\
Arg/Arg & $127(39.1)$ & $123(37.8)$ & 0.33 \\
Arg/Pro & $145(44.6)$ & $154(47.4)$ & \\
Pro/Pro & $53(16.3)$ & $48(14.8)$ & \\
FFI $^{\mathrm{b}}$ & & & \\
Arg/Arg & $83(41.3)$ & $77(38.3)$ & 0.099 \\
Arg/Pro & $83(41.3)$ & $94(46.8)$ & \\
Pro/Pro & $35(17.4)$ & $30(14.9)$ & \\
FHL & & & \\
Arg/Arg & $44(35.5)$ & $45(36.3)$ & 0.709 \\
Arg/Pro & $62(50.0)$ & $60(48.4)$ & \\
Pro/Pro & $18(14.5)$ & $19(15.3)$ & \\
\hline
\end{tabular}

a Overall, $\operatorname{Arg}(\mathrm{p}=0.61)$; Pro $(\mathrm{q}=0.39)$; $\mathrm{b}$ IFF, $\operatorname{Arg}(\mathrm{p}=0.62)$; Pro ( $\mathrm{q}=0.38) ;{ }^{\circ} \mathrm{HFL}, \operatorname{Arg}(\mathrm{p}=0.60)$; Pro ( $\left.\mathrm{q}=0.39\right)$ and the susceptibility genotype (Yang and Khoury, 1997). Assuming independence between genotype and exposure in the population, the expected value of $\mathrm{OR}_{\mathrm{CO}}$ becomes unity, and the odds ratio obtained from a case-only study measures the departure from the multiplicative joint effect of genotype and exposure (Yang and Khoury, 1997). Null hypothesis considers $\mathrm{OR}_{\mathrm{ca}}=1 ; \mathrm{OR}_{\mathrm{ca}}>1$ if the joint effect is more than multiplicative, and ORca $<1$ if the joint effect is less than multiplicative (e.g., additive) (Khoury and Flanders, 1996). Confidence intervals of case-only odds ratios can be obtained by using standard crude analyses or logistic models that control for the effects of other covariates (Yang and Khoury, 1997).

The outcome of such approach is the effect of gene-environment interaction on the risk of BBD. Thus, genetic dominance models were created to estimate the allele effect on interactions with environmental factors. When Arg/Arg genotype was considered as reference, dominant model was composed of Arg/Pro + Pro/Pro genotypes and recessive model was composed of Pro/Pro genotype. When Pro/Pro genotype was used as reference, dominant model was Arg/Arg + Arg/Pro genotypes and recessive model was composed of Arg/Arg genotype. Gene-environment interaction analyses were performed using non-conditional Logistic Regressions to estimate crude interaction odds ratio, with $95 \%$ confidence interval $(95 \% \mathrm{CI})$. Statistical analyses were performed using Statistical Package for Social Sciences (SPSS) for Windows, version 20.0.

\section{Results}

From 325 women included in the study, $62.8 \%$ were under 50 years old, and $37.7 \%$ self-declared reported being white. Non-proliferative lesion was the most frequent type of lesion (73.5\%), followed by proliferative lesion without atypia (19.4\%), and atypical hyperplasia (7.1\%). The frequency of polymorphic allele (Pro) was $39.0 \%$, whereas the frequency of Pro allele homozygous genotype was $16.7 \%$, heterozygous $45.5 \%$, and Arg allele homozygous genotype was $37.8 \%$ (Table 1 ). In both reference hospitals, genotypes distributions were in Hardy-Weinberg equilibrium ( $p$-value $>0.05$ ).

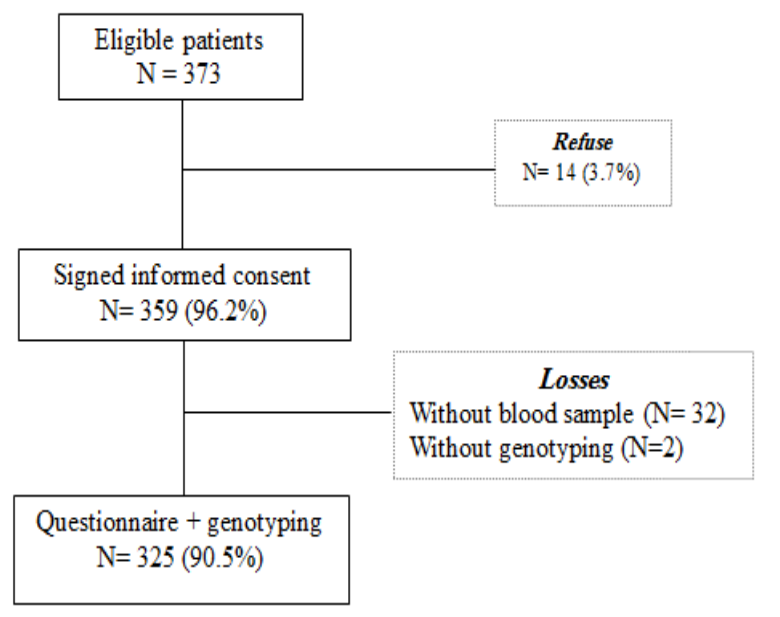

Figure 1. Flowchart of Patients Included in the Study 
Table2.DistributionofSociodemographicCharacteristics, Clinical Aspects, and Hormonal Exposures, According to Arg72Pro SNP Genotypes.

\begin{tabular}{|c|c|c|c|c|}
\hline \multirow[t]{2}{*}{ Variables } & \multicolumn{4}{|c|}{ Genotypes } \\
\hline & $\begin{array}{c}\operatorname{Arg} / \operatorname{Arg} \\
\text { N (\%) }\end{array}$ & $\begin{array}{c}\text { Arg/Pro } \\
\text { N (\%) }\end{array}$ & $\begin{array}{c}\text { Pro/Pro } \\
\text { N }(\%)\end{array}$ & p-value \\
\hline \multicolumn{5}{|l|}{ Age } \\
\hline$<50$ years & $78(61.4)$ & $91(62.8)$ & $35(66.0)$ & 0.843 \\
\hline$\geq 50$ years & $49(38.6)$ & $54(37.2)$ & $18(34.0)$ & \\
\hline \multicolumn{5}{|c|}{ Self-reported skin color } \\
\hline White & $54(42.5)$ & $52(36.1)$ & $16(30.2)$ & 0.261 \\
\hline Nonwhite & $73(57.5)$ & $92(63.9)$ & $37(69.8)$ & \\
\hline \multicolumn{5}{|l|}{ Histopathological } \\
\hline Non-proliferative & $94(74.0)$ & $105(72.4)$ & $40(75.5)$ & 0.872 \\
\hline $\begin{array}{r}\text { Proliferative } \\
\text { without atypia }\end{array}$ & $24(18.9)$ & $28(19.3)$ & $11(20.8)$ & \\
\hline Atypic hiperplasia & $9(7.1)$ & $12(8.3)$ & $2(3.8)$ & \\
\hline \multicolumn{5}{|l|}{ Menopause } \\
\hline No & $76(60.3)$ & $83(58.0)$ & $34(64.2)$ & 0.736 \\
\hline Yes & $50(39.7)$ & $60(42.0)$ & $19(35.8)$ & \\
\hline \multicolumn{5}{|c|}{ Use of hormone replacement ${ }^{\text {a }}$} \\
\hline Current or past & $4(10.5)$ & $3(6.4)$ & $2(15.4)$ & 0.57 \\
\hline Never & $34(89.5)$ & $44(93.6)$ & $11(84.6)$ & \\
\hline \multicolumn{5}{|c|}{ Use of oral contraceptive } \\
\hline Current or past & $100(78.7)$ & $114(79.2)$ & $41(77.4)$ & 0.963 \\
\hline Never & $27(21.3)$ & $30(20.8)$ & $12(22.6)$ & \\
\hline \multicolumn{5}{|l|}{ Alcohol consumption } \\
\hline Current or past & $54(42.5)$ & $46(31.7)$ & $17(32.1)$ & 0.146 \\
\hline Never & $73(57.5)$ & $99(68.3)$ & $36(67.9)$ & \\
\hline \multicolumn{5}{|c|}{ Age of alcohol use onset ${ }^{b}$} \\
\hline$\leq 20$ years & $32(61.5)$ & $28(63.6)$ & $7(41.2)$ & 0.251 \\
\hline$>20$ years & $20(38.5)$ & $16(36.4)$ & $10(58.8)$ & \\
\hline \multicolumn{5}{|l|}{ Smoking habit } \\
\hline Current or past & $43(33.9)$ & $35(24.1)$ & $13(24.5)$ & 0.169 \\
\hline Never & $84(66.1)$ & $110(75.9)$ & $40(75.5)$ & \\
\hline \multicolumn{5}{|l|}{ Smoking habit onset ${ }^{\mathrm{c}}$} \\
\hline$\leq 18$ years & $28(66.7)$ & $26(76.5)$ & $6(46.2)$ & 0.138 \\
\hline$>18$ years & $14(33.3)$ & $8(23.5)$ & $7(53.8)$ & \\
\hline \multicolumn{5}{|c|}{ Second-hand smoking ${ }^{d}$} \\
\hline No & $56(66.7)$ & $77(70.0)$ & $29(72.5)$ & 0.783 \\
\hline Yes & $28(33.3)$ & $33(30.0)$ & $11(27.5)$ & \\
\hline \multicolumn{5}{|c|}{ Age of second-hand smoking onset* e } \\
\hline$\leq 22$ years & $15(55.6)$ & $26(78.8)$ & $3(33.3)$ & 0.022 \\
\hline$>22$ years & $12(44.4)$ & $7(21.2)$ & $6(66.7)$ & \\
\hline \multicolumn{5}{|l|}{ Exposure to solvents* } \\
\hline No & $108(85.0)$ & $110(75.9)$ & $44(83.0)$ & 0.143 \\
\hline Yes & $19(15.0)$ & $35(24.1)$ & $9(17.0)$ & \\
\hline \multicolumn{5}{|c|}{ Exposure to hair productsf** } \\
\hline No & $5(3.9 \%)$ & $18(12.7)$ & $5(9.4)$ & 0.039 \\
\hline Yes & $122(96.1 \%)$ & $124(87.3)$ & $48(90.6)$ & \\
\hline \multicolumn{5}{|l|}{ Exposure to gasoline } \\
\hline No & $113(89.0)$ & $129(89.6)$ & $50(94.3)$ & 0.524 \\
\hline Yes & $14(11.0)$ & $15(10.4)$ & $3(5.7)$ & \\
\hline \multicolumn{5}{|l|}{ Exposure to fabric } \\
\hline No & $123(96.9)$ & $133(91.7)$ & $50(94.3)$ & 0.198 \\
\hline Yes & $4(3.1)$ & $12(8.3)$ & $3(5.7)$ & \\
\hline
\end{tabular}

Table 2. Continued

\begin{tabular}{|c|c|c|c|c|}
\hline \multirow[t]{2}{*}{ Variables } & \multicolumn{4}{|c|}{ Genotypes } \\
\hline & $\begin{array}{c}\mathrm{Arg} / \mathrm{Arg} \\
\mathrm{N}(\%)\end{array}$ & $\begin{array}{c}\text { Arg/Pro } \\
\text { N (\%) }\end{array}$ & $\begin{array}{c}\text { Pro/Pro } \\
\text { N (\%) }\end{array}$ & p-value \\
\hline \multicolumn{5}{|c|}{ Exposure to cleaning productsg } \\
\hline No & $119(93.7)$ & $124(85.5)$ & $48(90.6)$ & 0.086 \\
\hline Yes & $8(6.3)$ & $21(14.5)$ & $4(9.4)$ & \\
\hline \multicolumn{5}{|c|}{$\begin{array}{l}\text { *, Statistically significant difference (p-value }<0.05 \text { ); a, Only } \\
\text { for menopausal women; b, Only women who reported alcohol } \\
\text { consumption; c, Only women who reported smoking habit; }{ }^{\mathrm{d}} \text {, Only } \\
\text { women who did not report smoking habit; e, Only women who were } \\
\text { exposed to second-hand smoking; and never have smoked; f, Hair } \\
\text { dyes, straighteners, or relaxers; gExposure to chlorine, bleaches, } \\
\text { disinfectants, and liquid wax. }\end{array}$} \\
\hline
\end{tabular}

In Table 2 we present the distribution of sociodemographic characteristics, clinical aspects, and hormonal exposures, according to the Arg72Pro SNP. In these analyses we observed that domestic and occupational exposure to hair straighteners or dyes were statistically more frequent among women with $\mathrm{Arg} / \mathrm{Arg}$ genotype (96.1\%) when compared with women with another genotypes ( $\mathrm{p}$-value $=0.039$ ).

Considering Arg/Arg genotype as reference, a strong interaction between Pro/Pro genotype and use of hormone replacement among women in menopause was observed $(\mathrm{OR}=2.16 ; 95 \% \mathrm{CI}: 0.43,10.69)$, but without statistical significance (Table 3). Domestic and occupational exposures to solvents interacted with Arg/Pro genotype $(\mathrm{OR}=1.90 ; 95 \% \mathrm{CI}: 1.04,3.48)$, with statistical significance (Table-3). Statically significant interaction was observed between textile mill workers or seamstresses exposure to fabric and Arg/Pro genotype $(\mathrm{OR}=2.21 ; 95 \% \mathrm{CI}: 1.01,4.83)$. Statistically significant interactions were observed between chlorine, bleaches, disinfectants, and liquid wax exposures and Arg/Pro genotype $(\mathrm{OR}=2.52 ; 95 \% \mathrm{CI}: 1.07,5.91)$ (Table 3).

When compared with Pro/Pro genotype, a statistically significant positive interaction was observed between current/past alcohol consumption and the recessive model $(\mathrm{OR}=1.58 ; 95 \% \mathrm{CI}: 1.00,2.51)$ (Table 4). In addition, a strong interaction were observed between early onset of alcohol consumption ( $\leq 20$ years old) and Arg/Arg genotype $(\mathrm{OR}=2.14 ; 95 \% \mathrm{CI}: 0.86,5.30)$, but without statistical significance. Current or past smoking habit interacted with the recessive model $(\mathrm{OR}=1.60 ; 95 \% \mathrm{CI}: 0.98,2.51$ without statistical significance. Among those who have never smoked, a significant interaction was observed between second-hand smoking before 22 years of age and Arg/Pro genotype (OR=3.49;95\%CI:0.98,12.44), without statistical significance. Hair dyes, straighteners, or relaxers exposures interacted with the recessive model (OR=3.26;95\%CI:121,8.82) (Table 4).

\section{Discussion}

To the best of our knowledge, this was the first study to investigate frequencies of the genotypes of Arg72Pro SNP in women diagnosed with BBD as well as gene-environmental interaction between this SNP and the selected environmental exposures. Thus, Arg/Pro 
DOI:10.31557/APJCP.2020.21.12.3477

Gene-Environment Interaction Between Arg72pro Snp and Selected Environmental Exposures

Table 3. Gene-Environment Interaction between Arg72Pro SNP and the Selected Environmental Factors, Considering Arg/Arg Genotype as Reference

\begin{tabular}{|c|c|c|c|c|c|c|c|}
\hline \multirow[t]{2}{*}{ Variables } & \multirow{2}{*}{$\begin{array}{c}\text { Arg/Arg } \\
\text { (N) }\end{array}$} & \multicolumn{2}{|r|}{ Arg/Pro } & \multicolumn{2}{|r|}{ Pro/Pro } & \multirow{2}{*}{$\begin{array}{l}\text { Dominant model } \\
\text { OR Interaction } \\
(95 \% \mathrm{CI})\end{array}$} & \multirow{2}{*}{$\begin{array}{l}\text { Recessive model } \\
\text { OR }{ }_{\text {Interaction }} \\
(95 \% \mathrm{CI})\end{array}$} \\
\hline & & $(\mathrm{N})$ & $\begin{array}{l}\mathrm{OR}_{\text {Interaction }} \\
(95 \% \mathrm{CI})\end{array}$ & $(\mathrm{N})$ & $\begin{array}{l}\mathrm{OR}_{\text {Interaction }} \\
(95 \% \mathrm{CI})\end{array}$ & & \\
\hline \multicolumn{8}{|c|}{ Use of hormone replacement ${ }^{\text {a }}$} \\
\hline Never & 46 & 52 & 1 & 16 & 1 & 1 & 1 \\
\hline Current or past & 4 & 8 & $1.77(0.50,6.26)$ & 3 & $2.16(0.43,10.69)$ & $1.86(0.56,6.20)$ & $1.53(0.39,6.03)$ \\
\hline \multicolumn{8}{|c|}{ Exposure to solvents* } \\
\hline No & 107 & 107 & 1 & 44 & 1 & 1 & 1 \\
\hline Yes & 20 & 38 & $1.90(1.04,3.48)$ & 9 & $1.09(0.46,2.59)$ & $1.66(0.93,2.97)$ & $0.75(0.35,1.64)$ \\
\hline \multicolumn{8}{|l|}{ Exposure to fabric* } \\
\hline No & 117 & 122 & 1 & 48 & 1 & 1 & 1 \\
\hline Yes & 10 & 23 & $2.21(1.01,4.83)$ & 5 & $1.22(0.40,3.75)$ & $1.93(0.90,4.12)$ & $0.75(0.28,2.03)$ \\
\hline \multicolumn{8}{|c|}{ Exposure to cleaning products* b } \\
\hline No & 119 & 124 & 1 & 48 & 1 & 1 & 1 \\
\hline Yes & 8 & 21 & $2.52(1.07,5.91)$ & 5 & $1.55(0.48,4.97)$ & $2.25(0.98,5.14)$ & $0.87(0.32,2.37)$ \\
\hline
\end{tabular}

* Statistically significant; ${ }^{\text {, }}$ Only for menopausal women; ${ }^{\text {, }}$ Exposure to chlorine, bleaches, disinfectants. and liquid wax.

genotype was the most frequent in the studied population (44.6\%), followed by Arg/Arg genotype (39.1\%), and Pro/ Pro genotype (16.3\%). Although no study evaluated the frequency of this polymorphism in women with BBD so far, Brazilian authors of case-control studies estimating Arg72Pro SNP frequency in women diagnosed with breast

Table 4. Gene-Environment Interaction between Arg72Pro SNP and the Selected Environmental Factors, Considering Pro/Pro Genotype as Reference

\begin{tabular}{|c|c|c|c|c|c|c|c|}
\hline Variables & $\begin{array}{c}\text { Pro/Pro } \\
\text { (N) }\end{array}$ & $(\mathrm{N})$ & $\begin{array}{l}\text { Arg/Arg } \\
\text { OR Interaction } \\
\quad(95 \% \mathrm{CI})\end{array}$ & $(\mathrm{N})$ & $\begin{array}{l}\text { Arg/Pro } \\
\text { OR Interaction } \\
\quad(95 \% \mathrm{CI})\end{array}$ & $\begin{array}{l}\text { Dominant model } \\
\text { OR Interaction } \\
(95 \% \mathrm{CI})\end{array}$ & $\begin{array}{c}\text { Recessive model } \\
\text { OR Interaction } \\
(95 \% \mathrm{CI})\end{array}$ \\
\hline \multicolumn{8}{|c|}{ Alcohol consumption* } \\
\hline Never & 46 & 77 & 1 & 95 & 1 & 1 & 1 \\
\hline Current or past & 17 & 51 & $1.40(0.71,2.76)$ & 49 & $1.09(0.56,2.14)$ & $1.23(0.66,2.30)$ & $1.58(1.00,2.51)$ \\
\hline \multicolumn{8}{|l|}{ Alcohol use onset } \\
\hline Never & 36 & 77 & 1 & 95 & 1 & 1 & 1 \\
\hline$\leq 20$ years & 7 & 32 & $2.14(0.86,5.30)$ & 30 & $1.62(0.65,4.03)$ & $0.59(0.34,1.02)$ & $0.54(0.23,1.27)$ \\
\hline$>20$ years & 10 & 18 & $0.84(0.35,2.01)$ & 18 & $0.68(0.29,1.62)$ & $0.70(0.37,1.34)$ & $1.33(0.60,2.92)$ \\
\hline \multicolumn{8}{|l|}{ Smoking habit } \\
\hline Never & 40 & 87 & 1 & 107 & 1 & 1 & 1 \\
\hline Current or past & 13 & 41 & $1.45(0.70,3.00)$ & 37 & $1.06(0.51,2.20)$ & $1.35(0.69,2.64)$ & $1.60(0.98,2.61)$ \\
\hline \multicolumn{8}{|c|}{ Smoking habit onset } \\
\hline Never & 40 & 84 & 1 & 107 & 1 & 1 & 1 \\
\hline$\leq 18$ years & 6 & 28 & $1.99(0.76,5.22)$ & 28 & $1.74(0.67,4.53)$ & $1.86(0.75,4.61)$ & $1.56(0.88,2.77)$ \\
\hline$>18$ years & 7 & 14 & $0.92(0.34,2.45)$ & 8 & $0.43(0.14,1.25)$ & $0.65(0.26,1.62)$ & $1.67(0.77,3.62)$ \\
\hline \multicolumn{8}{|c|}{ Age of second-hand smoking onset a } \\
\hline Never & 29 & 56 & 1 & 72 & 1 & 1 & 1 \\
\hline$\leq 22$ years & 3 & 15 & $2.38(0.64,8.86)$ & 26 & $3.49(0.98,12.44)$ & $2.98(0.86,10.29)$ & $0.98(0.48,1.98)$ \\
\hline$>22$ years & 6 & 12 & $0.79(0.26,2.39)$ & 9 & $0.60(0.19,1.85)$ & $0.69(0.25,1.88)$ & $1.75(0.75,4.08)$ \\
\hline \multicolumn{8}{|c|}{ Exposure to gasoline } \\
\hline No & 50 & 116 & 1 & 126 & 1 & 1 & 1 \\
\hline Yes & 3 & 12 & $1.72(0.47,6.38)$ & 17 & $2.25(0.63,8.01)$ & $2.00(0.59,6.81)$ & $1.23(0.59,2.57)$ \\
\hline \multicolumn{8}{|c|}{ Exposure to hair products*b } \\
\hline No & 5 & 6 & 1 & 17 & 1 & 1 & 1 \\
\hline Yes & 48 & 122 & $2.12(0.62,7.27)$ & 124 & $0.76(0.26,2.17)$ & $1.11(0.40,3.07)$ & $3.26(1.21,8.82)$ \\
\hline
\end{tabular}


cancer observed distributions ranging from $8.0 \%$ to $55.5 \%$ for Arg/Arg genotype, from $40.3 \%$ to $60.0 \%$ for $\mathrm{Arg} / \mathrm{Pro}$ genotype, and from $4.2 \%$ to $32.0 \%$ for Pro/Pro genotype (Damin et al., 2006; Mayorano, 2008; Aoki et al., 2009; Portela De Melo et al., 2009; Ramalho, 2012; Almeida et al., 2016). Brazilian breast cancer studies showed Arg/Arg genotype frequencies ranging from $44.7 \%$ to $55.5 \%$ in the South of Brazil (Damin et al., 2006; Aoki et al., 2009; Portela De Melo et al., 2009); whereas in the Southeast and Northeast regions, Arg/Pro genotype was the most frequent, varying from $41.4 \%$ to $60 \%$ (Mayorano, 2008; Ramalho, 2012; Almeida et al., 2016).

Among groups of healthy women, we observed that the Arg/Pro genotype frequency ranged from $39.2 \%$ to $58.9 \%$. The highest frequencies were observed in Southern Brazil (46.3\% to 58.9\%) (Damin et al., 2006; Mayorano, 2008; Aoki et al., 2009; Portela De Melo et al., 2009; Almeida et al., 2016); whereas in the Southeastern region, frequencies of heterozygous genotype ranged from $39.2 \%$ to $42.4 \%$ (Mayorano, 2008; Almeida et al., 2016). Moreover, the Arg/Arg genotype is the second most frequent among groups of Brazilian healthy women, ranging from $33.3 \%$ to 45.0\%; whereas the Pro/Pro genotype ranged from 10.3\% to $16.1 \%$ (Damin et al., 2006; Mayorano, 2008; Aoki et al., 2009; Portela De Melo et al., 2009; Almeida et al., 2016).

Differences between studies can be explained by the mixture of races in Brazil, which began with Amerindians being colonized by Portuguese peoples who brought enslaved African peoples, as well as the long history of migration of the Arab, Jewish and European peoples, and more recently, of Japanese and Chinese peoples (Layton and Smith, 2017; Braganholi et al., 2017). Such differences may be reflected in variations of genotypes frequencies observed in different regions of the country. However, different genotyping methods used among studies may also affect genotyping determination. The PCR-RFLP method is a qualitative and error-prone method in determining Arg/Pro genotype. Determination of the SNP of heterozygous genotype depends on restriction enzyme quality, which can produce a partial digestion with time. Furthermore, such method depends on the observer's accuracy when evaluating the gel image. A replication analysis for $10 \%$ of samples was proceeded through PCR-RFLP, in order to validate the correct classification. In addition, the studied genotypes frequencies of the SNP were in HWE in the total sample as well as in each reference unit.

As breast cancer, BBD is a multifactorial disease, suggesting that a host single polymorphism might be insufficient to produce the disease phenotype, being necessary environmental factors interacting with gene polymorphism/mutations to affect the risk of disease (Ambrosone, 2007). Thus, cultural differences would play a role as in the life habits characteristic of each population, as in environmental exposures frequencies. However, biological mechanisms by which such gene-environmental interaction modulates the risk of BBD development are still unclear (Gray et al., 2017; Rodgers et al., 2018). Nevertheless, it is already known that environmental factors associated with breast cancer include endogenous and exogenous exposures to estrogen and progesterone, to tobacco and alcohol, as well as to specific chemical agents such as petroleum products, solvents, and endocrine disruptors (EDCss) found in cleaning products (Gray et al., 2017; Rodgers et al., 2018). In the present study, we observed a strong association between Arg allele and alcohol consumption, age at onset of alcohol consumption until 20 years, smoking habit, smoking onset until 18 years, passive smoking onset before 22 years, and domestic/occupational hair dye and smoothing exposures. On the other hand, the presence of at least one Pro allele was strongly associated with exposures to fabric, solvents and cleaning products such as chlorine, bleaches, disinfectants, and liquid wax.

These findings could be partially explained by the fact that p53 protein encoded by the Arg allele is more efficient for inducing apoptosis than DNA repair (Dumont et al., 2003; Pim and Banks, 2004). Therefore, exposures to alcohol, tobacco, and second-hand smoke could interact with this allele and increase BBD risks. In addition, evidences suggest that alcohol and tobacco consumption induce DNA damage, and such consumption has been associated with increased risk of BBD and breast cancer (Pflaum et al., 2016; Ma et al., 2019). Moreover, previous studies suggested that alcohol could act in the carcinogenesis process by two pathways. Firstly by ER and PR hyperstimulation, affecting the estrogen tissue sensitivity and leading to development of ER+ breast cancer tumors, and increasing estradiol circulating levels (Ellingjord-Dale et al., 2017); secondly, via DNA damage, causing increased oxidative stress (Zhao et al., 2017). Moreover, early age at onset of alcohol consumption may reflect both a greater opportunity for prolonged exposure, and exposure during critical period of biological development in women's breasts, in which there is greater susceptibility of BBD development (Byrne et al., 2002; Liu et al., 2012; Ellingjord-Dale et al., 2017).

There are several evidences according to which smoking acts from initiation to neoplastic progression, mainly in cells of epithelial origin (IARC Working Group on the Evaluation of Carcinogenic Risks to Humans, 2004). However, regarding breast cancer, literature is still expanding (IARC Working Group on the Evaluation of Carcinogenic Risks to Humans, 2004; IARC Working Group, 2007). Although the specific mechanisms involved in the association between smoking and TP53 gene mutations are still unclear, the hypothesis of addition of genotoxicity associated with smoking habits seems to be plausible, since cigarettes contain about 20 carcinogens recognized by IARC, among them aromatic hydrocarbons, nitrosamines, aliphatic compounds, arylamines, and nitroarenes(IARC Working Group on the Evaluation of Carcinogenic Risks to Humans, 2004). These carcinogens act on DNA through a bond that forms adducts (Ma et al., 2019). Our results corroborate other studies whose authors reported that passive smoking was also associated with increased risk for BBD (Liu et al., 2000). Researchers have strongly suggested that the breast tissue is a target for carcinogenic effects of cigarette smoke (Conway et al., 2002), because such is more inhaled and absorbed by passive smokers, which would lead to DNA damage just as it occurs to active smokers (Johnson et al., 2011; 
Li et al., 2015).

Nevertheless, the p53 protein encoded by Pro allele has been mostly efficiently related to DNA repair (Siddique et al., 2005; Zhuo et al., 2009). In our study the Pro allele statistically interacted with EDCs present in a wide range of products, being found in household insecticides, pesticides, detergents, cleaning products, solvents, hair products, and plastics. EDCs are also present in occupational exposure to fabrics among textile mill workers or seamstresses, since they are used in textile manufacturing industry compounds such as textile dyes, printings, fungicides, flame retardants, solvents, plastics, and moth repellents (IARC Working Group, 1990). These compounds are capable of deregulating ER expression, PR or HER2 gene, in addition to the expression of the p53 protein. Thus, one of the hypotheses to explain such finding is that such changes may be related to BBD development, as already observed in breast cancer (Gray et al., 2017).

Thus, according to our results, we suggest that deficiency in triggering apoptosis process in women with $\mathrm{Arg} /$ Pro genotype or at least one Pro allele, coupled with hormone receptors hyperstimulation promoted by solvents and cleaning products exposures could be modulating risk to $\mathrm{BBD}$. Moreover, domestic or occupational exposure to hair straighteners, relaxers, or dyes interacted with the presence of at least one Arg allele (dominant model), when compared with the Pro/Pro genotype. Such finding could be explained by the fact that hair products are also considered as EDCs (Gray et al., 2017; McDonald et al., 2018). EDCs has been associated with the development of DNA adducts, which in the presence of the Arg allele, can produce $\mathrm{p} 53$ protein with difficulty in achieving DNA repair (Thomas et al., 1999; Dumont et al., 2003; Pim and Banks, 2004).

Our study is the first one that described the Arg72Pro SNP distribution among women with benign breast disease, besides being pioneer in gene-environment interaction analysis between this SNP and the selected environmental exposures in BBD. For such analysis, we used the caseonly approach, whose findings are an efficient and valid approach to gene-environment interaction screening under the assumption of independence between exposure and genotype in the population (Dai et al., 2018). Another advantage of this type of approach is the reduction of selection and recall bias, which are more likely to occur in case-control studies; in addition to being more efficient and less costly than a case-control study. Moreover, this approach is ideal for initial investigations of geneenvironment interactions (Dai et al., 2018). Finally, another advantage of this study is the use of samples of two reference hospitals in Rio de Janeiro, with the largest sample size of Brazilian BBD studies.

However, this study has limitations that must be addressed. First, the low prevalence of hormonal replacement therapy, probably because the study population is in average very young and therefore with a low frequency of menopausal women. Another possible limitation would be the lack of statistical significance for strong gene-environment interactions between Arg72Pro SNP and important environmental factors, such as smoking habit, early age at smoking and alcohol use onset, early age at second-hand smoking, and exposure to gasoline. However, this may have occurred due to the small sample size. In addition, case only approach has as limitation that many biologically plausible modes of gene-environment interaction involve a departure from multiplicative effects and in case of additive joint effect, OR interaction derived from a case-only design can be questionable (Gauderman et al., 2019). Thus, future studies, with different study designs and larger sample size, are required to test hypotheses raised from this investigation.

\section{Acknowledgements}

Carlos Chagas Filho Foundation for Research Support of Rio de Janeiro State (FAPERJ) supported the present study under the number FAPERJ/SES-RJ/MS-DECIT/ $\mathrm{CNPq}$ / N. ${ }^{0} 35 / 2013$ - PPSUS. We are grateful for support from the Coordination for the Improvement of Higher Education Personnel (CAPES).

\section{Statement conflict of interest}

The authors declare that there are no conflicts of interest.

\section{References}

Almeida BC, Kleine JPFO, Camargo-Kosugi CM, et al (2016). Analysis of polymorphisms in codons 11, 72 and 248 of TP53 in Brazilian women with breast cancer. Genet Mol Res, 15, https://doi.org/10.4238/gmr.15017055

Ambrosone CB (2007). The promise and limitations of genomewide association studies to elucidate the causes of breast cancer. Breast Cancer Res BCR, 9, 114.

Aoki MN, da Silva do Amaral Herrera AC, Amarante MK, et al (2009). CCR5 and p53 codon 72 gene polymorphisms: implications in breast cancer development. Int $\mathrm{J} \mathrm{Mol} \mathrm{Med,}$ 23, 429-35.

Bodian CA, Perzin KH, Lattes R, et al (1993). Prognostic significance of benign proliferative breast disease. Cancer, 71, 3896-3907.

Bouaoun L, Sonkin D, Ardin M, et al (2016). TP53 variations in human cancers: new lessons from the IARC TP53 database and genomics data. Hum Mutat, 37, 865-76.

Braganholi DF, Ambrosio IB, Polverari FS, et al (2017). 500 years later: Understanding the genetic ancestry of the southeast region, brazil. Forensic Sci Int Genet Suppl Ser, 6, 370-1.

Bray F, Ferlay J, Soerjomataram I, et al (2018). Global cancer statistics 2018: GLOBOCAN estimates of incidence and mortality worldwide for 36 cancers in 185 countries. $C A$ Cancer J Clin, 68, 394-424

Byrne C, Webb PM, Jacobs TW, et al (2002). Alcohol consumption and incidence of benign breast disease. Cancer Epidemiol Biomark Prev Publ Am Assoc Cancer Res Cosponsored Am Soc Prev Oncol, 11, 1369-74.

Chapa J, An G, Kulkarni SA (2016). Examining the relationship between pre-malignant breast lesions, carcinogenesis and tumor evolution in the mammary epithelium using an agent-based model. PLoS One, 11, e0152298.

College of American Pathologists (1986). Is "fibrocystic disease" of the breast precancerous? A consensus report from the College of American Pathologists. Indiana Med J Indiana 
State Med Assoc, 79, 753-4.

Conway K, Edmiston SN, Cui L, et al (2002). Prevalence and spectrum of $\mathrm{p} 53$ mutations associated with smoking in breast cancer. Cancer Res, 62, 1987-95.

Dai JY, Liang CJ, LeBlanc M, et al (2018). Case-only approach to identifying markers predicting treatment effects on the relative risk scale. Biometrics, 74, 753-63.

Damin APS, Frazzon APG, Damin DC, et al (2006). Evidence for an association of TP53 codon 72 polymorphism with breast cancer risk. Cancer Detect Prev, 30, 523-9.

Done SJ, Eskandarian S, Bull S, et al (2001). p53 missense mutations in microdissected high-grade ductal carcinoma in situ of the breast. J Natl Cancer Inst, 93, 700-4.

Donehower LA, Soussi T, Korkut A, et al (2019). Integrated analysis of TP53 gene and pathway alterations in The Cancer Genome Atlas. Cell Rep, 28, 1370-84.e5.

Dumont P, Leu JI-J, Della Pietra AC, et al (2003). The codon 72 polymorphic variants of p53 have markedly different apoptotic potential. Nat Genet, 33, 357-65.

Dupont WD, Page DL (1987). Breast cancer risk associated with proliferative disease, age at first birth, and a family history of breast cancer. Am J Epidemiol, 125, 769-79.

Ellingjord-Dale M, Vos L, Hjerkind KV, et al (2017). Alcohol, physical activity, smoking, and breast cancer subtypes in a large, nested case-control study from the Norwegian Breast Cancer Screening Program. Cancer Epidemiol Biomark Prev Publ Am Assoc Cancer Res Cosponsored Am Soc Prev Oncol, 26, 1736-44.

Ellingjord-Dale M, Vos L, Tretli S, et al (2017). Parity, hormones and breast cancer subtypes - results from a large nested case-control study in a national screening program. Breast Cancer Res BCR, 19, 10.

Gauderman WJ, Kim A, Conti DV, et al (2019). A Unified Model for the Analysis of Gene-Environment Interaction. Am J Epidemiol, 188, 760-7.

Gray JM, Rasanayagam S, Engel C, Rizzo J (2017). State of the evidence 2017: an update on the connection between breast cancer and the environment. Environ Health Glob Access Sci Source, 16, 94.

IARC Working Group (ed) (2007). IARC monographs on the evaluation of carcinogenic risks to humans, volume 90 , Human papillomaviruses: this publication represents the views and expert opinions of an IARC Working Group on the Evaluation of Carcinogenic Risks to Humans, which met in Lyon, 15 - 22 February 2005. IARC, Lyon

IARC Working Group (1990). Some flame retardants and textile chemicals, and exposures in the textile manufacturing industry. IARC Monogr Eval Carcinog Risks Hum, 48, $1-278$.

IARC Working Group on the Evaluation of Carcinogenic Risks to Humans (2010). Alcohol consumption and ethyl carbamate. IARC Monogr Eval Carcinog Risks Hum, 96, 3-1383.

IARC Working Group on the Evaluation of Carcinogenic Risks to Humans (2004). Tobacco smoke and involuntary smoking. IARC Monogr Eval Carcinog Risks Hum, 83, 1-1438.

INMETRO (1994). Normalização e Qualidade Industrial.

Johnson KC, Miller AB, Collishaw NE, et al (2011). Active smoking and secondhand smoke increase breast cancer risk: the report of the Canadian Expert Panel on Tobacco Smoke and Breast Cancer Risk (2009). Tob Control, 20, 2.

Khoury MJ, Flanders WD (1996). Nontraditional epidemiologic approaches in the analysis of gene-environment interaction: case-control studies with no controls!. Am J Epidemiol, 144, 207-13.

Kresovich JK, Erdal S, Chen HY, et al (2019). Metallic air pollutants and breast cancer heterogeneity. Environ Res, 177, 108639.
Kumar R, Dunn LL (1989). Designed diagnostic restriction fragment length polymorphisms for the detection of point mutations in ras oncogenes. Oncogene Res, 4, 235-41.

Layton ML, Smith AE (2017). Is it race, class, or gender? The Sources of Perceived Discrimination in Brazil. Lat Am Polit Soc, 59, 52-73.

Li B, Wang L, Lu M-S, et al (2015). Passive smoking and breast cancer risk among non-smoking women: A Case-Control Study in China. PLoS One, 10, e0125894.

Liu L, Wu K, Lin X, et al (2000). Passive smoking and other factors at different periods of life and breast cancer risk in Chinese women who have never smoked - A Case-control Study in Chongqing, People's Republic of China. Asian Pac J Cancer Prev, 1, 131-7.

Liu Y, Tamimi RM, Berkey CS, et al (2012). Intakes of alcohol and folate during adolescence and risk of proliferative benign breast disease. Pediatrics, 129, 1192-8.

Ma B, Stepanov I, Hecht SS (2019). Recent studies on DNA adducts resulting from human exposure to Tobacco smoke. Toxics, 7.

Mayorano MB (2008). Polimorfismos dos genes TP53 e MDR-1, susceptibilidade e resposta à quimioterapia neoadjuvante em pacientes com câncer de mama. Universidade de São Paulo.

McDonald JA, Tehranifar P, Flom JD, et al (2018). Hair product use, age at menarche and mammographic breast density in multiethnic urban women. Environ Health Glob Access Sci Source, 17, 1.

Miller SA, Dykes DD, Polesky HF (1988). A simple salting out procedure for extracting DNA from human nucleated cells. Nucleic Acids Res, 16, 1215.

Minami Y, Ohuchi N, Taeda Y, et al (1999). Risk of breast cancer in Japanese women with benign breast disease. Jpn J Cancer Res Gann, 90, 600-6.

Nomura Y, Tashiro H, Katsuda Y (1993). Benign breast disease as a breast cancer risk in Japanese women. Jpn J Cancer Res Gann, 84, 938-44.

Page DL, Dupont WD (1993). Anatomic indicators (histologic and cytologic) of increased breast cancer risk. Breast Cancer Res Treat, 28, 157-66.

Palli D, Rosselli del Turco M, Simoncini R, Bianchi S (1991). Benign breast disease and breast cancer: a case-control study in a cohort in Italy. Int $J$ Cancer, 47, 703-6.

Pflaum T, Hausler T, Baumung C, et al (2016). Carcinogenic compounds in alcoholic beverages: an update. Arch Toxicol, 90, 2349-67.

Piegorsch WW, Weinberg CR, Taylor JA (1994). Nonhierarchical logistic models and case-only designs for assessing susceptibility in population-based case-control studies. Stat Med, 13, 153-62.

Pim D, Banks L (2004). p53 polymorphic variants at codon 72 exert different effects on cell cycle progression. Int $J$ Cancer, 108, 196-9.

Portela De Melo M, Bittelbrunn AC, Menke CH, et al (2009). Analysis of the R72P polymorphism of the TP53 gene in patients with invasive ductal breast carcinoma. Mol Med Rep, 2, 793-7.

Ramalho EAV de F (2012). Avaliação de alterações nos genes p53, BRCA1 em Carcinoma Ductal Invasivo de Mama (CDI). Universidade Federal de Pernambuco.

Rodgers KM, Udesky JO, Rudel RA, Brody JG (2018). Environmental chemicals and breast cancer: An updated review of epidemiological literature informed by biological mechanisms. Environ Res, 160, 152-82.

Siddique MM, Balram C, Fiszer-Maliszewska L, et al (2005). Evidence for selective expression of the p53 codon 72 polymorphs: implications in cancer development. Cancer Epidemiol Biomark Prev Publ Am Assoc Cancer Res 
Cosponsored Am Soc Prev Oncol, 14, 2245-52.

Själander A, Birgander R, Saha N, et al (1996). p53 polymorphisms and haplotypes show distinct differences between major ethnic groups. Hum Hered, 46, 41-8.

Thomas M, Kalita A, Labrecque S, et al (1999). Two polymorphic variants of wild-type p53 differ biochemically and biologically. Mol Cell Biol, 19, 1092-1100.

Tsuda H (2009). Gene and chromosomal alterations in sporadic breast cancer: correlation with histopathological features and implications for genesis and progression. Breast Cancer Tokyo Jpn, 16, 186-201.

Wrensch MR, Petrakis NL, Miike R, et al (2001). Breast cancer risk in women with abnormal cytology in nipple aspirates of breast fluid. J Natl Cancer Inst, 93, 1791-8.

Yang Q, Khoury MJ (1997). Evolving methods in genetic epidemiology. III. Gene-environment interaction in epidemiologic research. Epidemiol Rev, 19, 33-43.

Zhao M, Howard EW, Guo Z, et al (2017). p53 pathway determines the cellular response to alcohol-induced DNA damage in MCF-7 breast cancer cells. PLoS One, 12, 0175121.

Zhuo W, Zhang Y, Xiang Z, et al (2009). Polymorphisms of TP53 codon 72 with breast carcinoma risk: evidence from 12226 cases and 10782 controls. J Exp Clin Cancer Res CR, 28, 115 .

\section{(c) (i) (8)}

This work is licensed under a Creative Commons AttributionNon Commercial 4.0 International License. 